STRATEGIES FOR HEALTH CARE FINANCE IN DEVELOPING COUNTRIES 


\section{ECONOMIC ISSUES IN HEALTH CARE}

General editors

Professor Gavin Mooney

Health Economics Research Unit

Department of Public Health

Medical School

University of Aberdeen

Aberdeen AB9 2ZD, Scotland
Dr Alistair McGuire

Centre for Socio-Legal Studies and Pembroke College

University of Oxford

Oxford OX2 6UD, England

Published titles in the series:

The Challenges of Medical Practice Variations

Edited by Tavs Folmer Andersen and Gavin Mooney

Competition in Health Care: Reforming the NHS

Edited by A.J. Culyer, Alan Maynard and John Posnett

Strategies for Health Care Finance in Developing Countries

By Guy Carrin with Marc Vereecke

Forthcoming titles in the series:

The Economics of Health Care Financing

By Cam Donaldson and Karen Gerard

Private Exchange and Public Interest

By John Forbes

Why Wait? Tackling Waiting Lists in the NHS

Edited by Stephen J. Frankel and R. R. West

Just Managing-Power and Culture in the NHS

By Stephen Harrison, David J. Hunter and Gordon Marnoch

Dental Care: An Economic View

By David Parkin and Brian Yule 


\section{STRATEGIES FOR HEALTH CARE FINANCE IN DEVELOPING COUNTRIES}

with a focus on community financing in Sub-Saharan Africa

\section{Guy Carrin}

Department of Economics

University of Antwerp, Belgium and

School of Public Health

Boston University, USA

with

Marc Vereecke

Department of Economics

University of Antwerp, Belgium

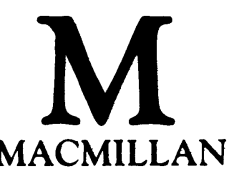


(C) The authors and contributors 1992

Softcover reprint of the hardcover 1st edition 1992 978-0-333-51945-5

All rights reserved. No reproduction, copy or transmission of this publication may be made without written permission.

No paragraph of this publication may be reproduced, copied or transmitted save with written permission or in accordance with the provisions of the Copyright, Designs and Patents Act 1988, or under the terms of any licence permitting limited copying issued by the Copyright Licensing Agency, 90 Tottenham Court Road, London W1P 9HE.

Any person who does any unauthorized act in relation to this publication may be liable to criminal prosecution and civil claims for damages.

First published 1992 by

THE MACMILLAN PRESS LTD

Houndmills, Basingstoke, Hampshire RG21 2XS

and London

Companies and representatives

throughout the world

ISBN 978-0-333-51946-2 ISBN 978-1-349-22396-1 (eBook)

DOI 10.1007/978-1-349-22396-1

A catalogue record for this book is available from the British Library.

Filmset by Wearset, Boldon, Tyne and Wear 


\section{Contents}

Preface

vii

The authors and contributors $\quad \mathbf{x}$

\section{Part 1}

TOWARDS BETTER HEALTH THROUGH COMMUNITY

FINANCING IN POOR COUNTRIES

Guy Carrin with Marc Vereecke

1. Triggering further progress in health in the developing world

2. Linkages between health, health financing and the economy

3. Lessening the constraints on health development

4. Economic analysis of community financing schemes

\section{Part 2}

CASE STUDIES OF COMMUNITY FINANCING

5. Direct payment for drugs at the public pharmacy in Fianga (Chad)

Guy Carrin, Philippe Autier, Barou Djouater and Marc Vereecke

6. The role of user fees in financing health care at government health centres in $\mathbf{R}$ wanda

Donald S. Shepard, Guy Carrin and Prosper Nyandagazi

7. Appraisal of the utilization of health care in the district of Kita (Mali)

Guy Carrin, Go Kegels, Sanousi Konaté, Marc Réveillon and Marc Vereecke 
8. The Pikine project in Senegal: Fifteen years of experience in 136 financing urban primary health care

Guy Carrin, Michel Jancloes, Emile Jeannée, Salif Guindo, Birama

Ndiaye, Marc Réveillon and André Stroobant

9. Prepayment for hospital care in the Bwamanda health zone (Zaire)

Freddy Moens and Guy Carrin

10. Main lessons from the practice of community financing schemes

Guy Carrin and Marc Vereecke

Appendix: List of Exchange Rates

Index 


\section{Preface}

During the last decade, health care finance in developing countries has become an important subject of scientific reflection and debate. One of the main reasons is that quite a number of developing countries, especially those of Sub-Saharan Africa, experienced a long-term economic decline, and hence found it increasingly difficult to allocate sufficient funds to the public health sector. However, apart from these financial difficulties, it also became increasingly apparent that governments, again mostly those of the poorest countries, continued to lack the administrative capacities to engage in effective nationwide health care financing.

As an answer to constraints on spending in the public health sector, and to mobilize resources other than those of the government, cost recovery schemes were established in various countries. One particular form of cost recovery is community financing, involving the financial participation of well-defined communities, such as the population of a city or of a rural district. In principle, community financing also supposes some population participation in the management of a scheme. However, community financing schemes are not shaped according to one particular model. In some, the population pays directly for medicines; in others, the population participates via a fee-for-service or a prepayment system. In some, the central government still finances part of recurrent costs; others have complete financial autonomy. Some community financing schemes organize the financing of primary health care, while others focus upon hospital care only.

The purpose of this book is to help to clarify the current and potential role of community financing methods in the securing of resources for health, especially in Sub-Saharan Africa. The book also identifies why, in specific settings, community financing was judged to be a suitable way of financing health care. Given this emphasis the book finds a very natural home in the series concerned with Economic Issues in Health Care, where change is the key theme. The first part of the book begins with a reflection on the current state of health in developing countries (Chapter 1). We also review the various influences on health status and 
provide an initial discussion of the financing of health determinants. In Chapter 2, we present and analyse a simple model of the linkages between the functioning of the health sector and that of the economy at large. We discuss in Chapter 3 the various possibilities of coping with the constraints on public health development in developing countries. In this chapter, alternative methods of health care finance are also studied. We also identify the specific reasons why it may be rational for well-defined populations to engage in community financing. We provide a detailed economic analysis of community financing in Chapter 4 . This last chapter also discusses how the criteria of economic efficiency, administrative efficiency and equity can be used when evaluating community financing schemes in practice.

In the second part of the book, case studies of community financing schemes are presented and analysed. We study the system of direct payment for drugs in Fianga (Chad) in Chapter 5. In Chapters 6 to 8, respectively, the fee-for-service systems in Rwanda, Kita (Mali) and Pikine (Senegal) are presented. Chapter 9 focuses on the prepayment scheme for hospital care in Bwamanda (Zaire). One of the main objectives of the case studies is to learn how schemes came into being and how they currently operate. Furthermore, each scheme is evaluated using the criteria of efficiency and equity defined earlier in Chapter 4. We also reflect upon the possible direction each scheme may take in the future. In the last chapter overall lessons from the five case studies and from a selected number of other community financing schemes are presented.

Preliminary research for this book was started while I was on leave from the University of Antwerp in 1985-86 and serving as a Takemi Fellow in International Health at the Harvard School of Public Health. I am grateful to Professors David Bell, William Hsiao, Michael and Don Shepard of Harvard University, as well as to my Takemi colleagues Mitsuru Fujii, Uriel Kitron, El Fateh El-Samani, Sam Samarasinghe and Tomas Uribe for many suggestions and critical remarks on earlier research papers in the field of health financing. Over the years, I became involved in applied health economics analysis of financing schemes in Sub-Saharan Africa. This has led to the series of case studies in this book. The case study on health financing in Rwanda also appeared, but in another format, in the book Health Economics Research in Developing Countries edited by Ken Lee and Ann Mills. The Bwamanda prepayment scheme was also discussed by F. Moens in last year's volume of Social Science and Medicine.

Various chapters have been used as background papers for a series of lectures I have been giving at the Boston University School of Public Health since 1987. These lectures are part of a course on Financing Health Care in Developing Countries, organized by the Office of Special 
Projects of Boston University's School of Public Health. I thank in particular the Course Director Professor William Bicknell and Assistant Directors Sarah Degnan, Michael Devlin and Michael Trisolini for providing me each time with a stimulating work environment. Many participants on these courses commented on earlier versions of the book and gave advice enabling me to apply health economics concepts better to the reality of the third world. Among my former students, I would like to cite especially Miaka Mia Belenge, Sabri Belgacem, Somsak Chunharas, Mahamane Kalil Maiga, Olusegun Oshin and Martin van $\mathrm{Zijl}$ for their interest.

The financial support of the Interuniversitair College voor Managementwetenschappen (ICM, Brussels), the University of Antwerp (UFSIA) and the Takemi Program in International Health of the Harvard School of Public Health in the early stages of the research is gratefully acknowledged. Various organizations co-financed the empirical research that constitutes the second part of this book: Médecins sans Frontières (Chapter 5), United States Agency of International Development and the World Bank (Chapter 6), Medicus Mundi Belgium and the Belgian Agency for Development Cooperation (Chapters 7 and 8). Dr. Claude Bourlard of Medicus Mundi is thanked for his fruitful collaboration while preparing the field studies in Pikine and Kita.

I owe a special debt to the Belgian Francqui Foundation for its financial support during the preparation of the final manuscript. I would like to mention especially the contribution of Marc Vereecke to this book. He provided very capable research assistance and helped to shape the book. Thanks also to Leo Devillé, Kodjo Evlo and Alejandro Herrin who provided useful ideas and critical comments. Last but not least, the Series Editors proved stimulating critics and gave very valuable advice throughout the preparation of the manuscript. At present, I am a staff member of the World Health Organization (Geneva). However, this organization is not responsible for the views expressed in this book. 


\section{The Authors and Contributors}

Philippe Autier, M.D., M.P.H. was a staff member of Médecins sans Frontières and the Association Européenne pour le Développement et la Santé, Brussels, Belgium

Guy Carrin, Ph.D. is Professor of Economics at the University of Antwerp (Belgium) and Adjunct Professor of Public Health at Boston University (USA). At present, he is seconded to the World Health Organization, Geneva, Switzerland, where he is a health economist in the Director-General's Office

Barou Djouater was Director of Pharmacies, Ministry of Public Health, Ndjamena, Chad

Salif Guindo, M.D. was Chief Medical Officer of the Health Department of Pikine, Senegal

Michel Jancloes, M.D., D.P.H. is Chief of the Office of International Cooperation, Director-General's Office, World Health Organization, Geneva

Emile Jeannée, M.D., M.P.H. was Director of the Pikine Project, Pikine, Senegal. He is currently affiliated with the Swiss Tropical Institute, Basel, Switzerland

Go Kegels, M.D. was a staff member of Medicus Mundi, Brussels, Belgium, and the Projet de Développement Sanitaire, Bamako, Mali

Sanousi Konaté, M.D. was Director of the Projet de Développement Sanitaire, Bamako, Mali 
Freddy Moens, M.D., M.P.H. was Chief Medical Officer of the Health Zone of Bwamanda, Zaire. He is now Project Officer at Medicus Mundi, Brussels, Belgium

Birama Ndiaye is President of the Association pour la Promotion de la Santé, Pikine, Senegal

Prosper Nyandagazi was Director of Finance and Administration, Ministry of Public Health and Social Affairs, Kigali, Rwanda

Marc Réveillon, M.A. is an economist and was a staff member of the Pikine Project. He is also an adviser to Medicus Mundi, Brussels, Belgium

Donald S. Shepard, Ph.D. is currently with the Bigel Institute for Health Policy, Brandeis University, Waltham, MA, USA

Andre Stroobant, M.D. is Head of the Unit of Epidemiology at the Institute of Hygiene of the Ministry of Public Health, Brussels, Belgium, and adviser to Medicus Mundi, Brussels, Belgium

Marc Vereeke, B.A. is an economist and researcher in health economics at the University of Antwerp, Belgium. At present he pursues graduate studies in development economics and demography at the Université Catholique de Louvain, Louvain-la-Neuve, Belgium 